\title{
Evaluasi Kebijakan 5 Hari Kerja Terhadap Pencapaian Standar Pelayanan Minimal Pada Dinas Pendidikan Kota Mataram
}

\author{
Ibnu Jauji 1)*, Sudirman Wilian ${ }^{2)}$, Untung Waluyo ${ }^{3)}$ \\ ${ }^{1,2,3}$ Magister Administrasi Pendidikan \\ email: ibnujauji016@gmail.com
}

\begin{abstract}
This study aims to reveal employee performance on the effectiveness of the 5 working day policy in improving the implementation of the Minimum Service Standards at the Mataram City Education Office and to explain the factors inhibiting the implementation of 5 working days in relation to the achievement of Minimum Service Standards at the Mataram City Education Office. This research uses a qualitative approach with descriptive methods. This research was conducted at the Mataram City Education Office. Collecting data using observation, interviews and documentation. The data analysis technique uses three activity lines, namely data reduction, data presentation and conclusion drawing. Validity data using analysis techniques of credibility, transferability, dependability and confirmability. The results of this study indicate that the five-day work policy, both regarding the use of time and work discipline, work intensity, work initiative, and work atmosphere in the five working day policy collectively contributes positively to the work productivity of the Mataram City national education office employees. Employees feel happy with the policies implemented by the Education Office so that employee performance can increase towards achieving minimum service standards.
\end{abstract}

Keywords: Evaluation, 5 Working Days Policy, Minimum Service Standards

Abstrak: Penelitian ini bertujuan untuk mengungkap kinerja pegawai terhadap efektivitas kebijakan 5 hari kerja dalam meningkatkan pelaksanaan Standar Pelayanan Minimal di Dinas Pendidikan Kota Mataram dan menjelaskan faktor-faktor penghambat pelaksanaan 5 hari kerja dalam kaitannya dengan pencapaian Standar pelayanan Minimal di Dinas Pendidikan Kota Mataram. Penelitian ini menggunakan pendekatan kualitatif dengan metode deskriptif. Penelitian ini dilakukan di Dinas Pendidikan Kota Mataram. Pengumpulan data menggunakan observasi, wawancara dan dokumentasi. Teknik analisis data menggunakan tiga alur kegiatan yaitu reduksi data, penyajian data dan penarikan kesimpulan. Kebashan data menggunakan teknik analisis kredibilitas, transferabilitas, dependabilitas dan konfirmabilitas. Hasil penelitian ini menunjukkan bahwa kebijakan lima hari kerja, baik yang menyangkut penggunaan waktu dan disiplin kerja, intensitas kerja, inisiatif kerja, serta suasana kerja dalam kebijakan lima hari kerja secara bersama-sama memberikan sumbangan positif terhadap produktivitas kerja pegawai dinas pendidikan nasional Kota Mataram. Pegawai merasa senang dengan kebijakan yang diterapkan oleh Dinas Pendidikan sehingga kinerja pegawai dapat meningkat terhadap pencapaian standar pelayanan minimal.

Kata Kunci:Evaluasi, Kebijakan 5 Hari Kerja, Standar Pelayanan Minimal

\section{PENDAHULUAN}

Dewasa ini instansi pemerintahan dituntut mampu menciptakan kinerja pegawai yang tinggi dalam rangka memenuhi tuntutan standar pelayanan publik yang minimal. Dengan adanya standar tersebut pemerintah dituntut mampu membangun sekaligus meningkatkan kinerja pegawai di lingkungannya. Keberhasilan pemerintah di 
dalam mencapai kinerja yang demikian itu dipengaruhi oleh sejumlah factor seperti disiplin kerja yang tinggi, ketepatan waktu dalam memberikan layanan, profesionalisme kerja dan lain sebagainya. Seluruh factorfaktor tersebut bermuara pada kualitas sumber daya manusia yang ada di dalamnya.

Mangkunegara (2007) menjelaskan bahwa kinerja seseorang dalam suatu organisasi sangat dipengaruhi oleh faktor kompetensi (kemampuan) dan motivasi mereka dalam mengemban tugas-tugas yang diberikan oleh atasan mereka. Jika seseorang karyawan memiliki kompetensi yang memadai untuk jabatan tertentu yang diembannya, ia dapat menggerakkan segala potensinya untuk mencapai kinerja maksimal sesuai dengan jabatan yang diamanatkan kepadanya. Perkembangan kompetensi ini umumnya didorong motivasi dari dalam diri sendiri untuk menghasikan kinerja yang sebaik-baiknya. Ketika motivasi terbentuk dengan baik, sikap pegawai dalam menjalankan tugas kerja selalu berorintasi pada pencapaian hasil layanan yang terbaoik bagi masyarakat yang dilayaninya.

Berdasarkan uraian di atas, dapat disimpulkan bahwa pengembangan kompetensi pegawai perlu dilakukan secara terus menerus agar mereka dapat terus memperbaiki kinerjanya dan meningkatkan kemampuannya dalam memanfaatkan sumber daya yang dimiliki oleh pemerintah. Pandangan ini menyiratkan bahwa pembinaan dan pengembangan sumber daya manusia dalam suatu insansi pemerintah memegang peranan sangat penting dalam meningkatkan kinerja pemerintah. Tidak dapat dipungkiri bahwa sumber daya manusia memiliki potensi yang besar untuk menjalankan aktivitas pemerintahan. Karenanya, potensi setiap sumber daya manusia yang ada di dalam instansi pemerintah harus terus dibina sebaik-baiknya sehingga mampu memberikan hasil kerja yang optimal.

Terkait dengan uraian di atas, Dinas Pendidikan Kota Mataram yang merupakan sebuah Organisasi atau Instansi
Berdasarkan Peraturan Daerah Kota Mataram Nomor 5 Tahun 2008 mempunyai tugas pokok membantu Walikota Mataram dalam menyelenggarakan kewenangan daerah di bidang Pendidikan.

Dalam melaksanakan tugastugasnya, pegawai negeri sipil di lingkungan Dikpora diarahkan untuk mencapai tujuan lembaga semaksimal mungkin. Salah satu faktor yang menjadi kriteria tercapainya tujuan suatu organisasi atau instansi adalah melalui identifikasi dan pengukuran kinerja pegawainya. Apabila seorang pegawai mampu mencapai tujuan yang telah ditetapkan, maka dapat dikatakan bahwa ia telah berkontribusi positif bagi kinerja lembaganya.

Seiring dengan perkembangan zaman, semua organisasi dituntut untuk dapat bersaing memberikan pelayanan yang maksimal, tidak terkecuali organisasi pemerintah yakni Dinas pendidikan Kota Mataram. Ini berarti bahwa aparat pemerintah sebagai abdi masyarakat dan abdi pemerintah, dituntut mampu untuk memberikan pelayanan yang terbaik kepada masyarakat karena hal tersebut sudah merupakan salah satu fungsi yang harus dijalankan oleh pemerintah dalam mengemban tugas sebagai penyelenggara pemerintahan, baik di tingkat pusat maupun daerah daerah. Tercapainya atau tidaknya tujuan organisasi tersebut sangat ditentukan oleh kinerja para pegawai dalam menjalankan tugasnya. Setiap organisasi pada umumnya mengharapkan para pegawainya mampu melaksanakan tugasnya dengan efektif, efisien, produktif dan profesional. Semua ini bertujuan agar organisasi dapat menghasilkan kualitas pelayanan public, yang sesuai dengan harapan masyarakat.

Selanjutnya, istilah pelayanan publik menurut Kepmen PAN Nomor 25 Tahun 2004, didefiniskan sebagai segala kegiatan pelayanan yang dilaksanakan oleh penyelenggara pelayanan publik sebagai upaya pemenuhan kebutuhan penerima pelayanan, maupun dalam rangka 
pelaksanaan penentuan peraturan perundangundangan. Dalam hal ini Pasolong (2011) menegaskan bahwa pelayanan publik meliputi segala kegiatan yang dilakukan oleh pemerintah terhadap sejumlah manusia yang memiiliki setiap kegiatan yang menguntungkan dalam suatu kumpulan atau kesatuan dan menawarkan kepuasan meskipun hasilnya tidak terikat pada suatu produk secara fisik. Dalam hal yang sama Ratminto dan Winarsih (2012) menguaraikan bahwa pelayanan publik adalah segala bentuk jasa pelayanan, baik dalam bentuk barang public maupun jasa publik yang pada prinsipnya menjadi tanggung jawab dan dilaksanakan oleh instansi pemerintah di Pusat, Daerah, dan di lingkungan Badan Usaha Milik Negara atau Badan Usaha Milik Daerah. Semua ini dilaksanakan, dalam rangka pemenuhan kebutuhan masyarakat maupun dalam rangka pelaksanaan ketentuan peraturan perundang-undangan.

Terkait dengan hal di atas, persoalan yang serimg menjadi perbincangan di media masa maupun social media adalah belum maksimalnya kualitas pelayanan instansi pemerintah. Meskipun pemerintah menegaskan bahwa reformasi birokrasi terus digulirkan keluhan masalah ketidakefektifan pemberian layanan pemerintah berlangsung masih cukup tinggi. Berbagai upaya pemenuhan layanan public bagi kebutuhan masyrakat telah dilakukan oleh pemerintah, sejauh ini tingkat layanan yang diberikan oleh pemerintah masih belum mampu memnuhi ekspektasi publik. Artinya persoalan kualitas fsn efektivitas pelayanan masih menjadi isu besar bagi pemerintah, khususnya Pemda Kota Mataram. Karena alas an ini lah, peneliti ingin meneliti apakah kebijakan pelayanan 5 hari kerja dapat memacy pegawai kantor Dikpora Kota Mataram untuk bekerja maksimal.

Penelitian ini mencoba mengkonfirmasi sejauh mana kebijakan 5 hari kerja ini mampu meningkatkan standar pelayanan minimal pada Dinas pendidikan Kota Mataram. Peneliti berasumsi bahwa kebijakan 5 hari kerja akan membawa dampak terhadap koordinasi dan pemberian layanan oleh kantor Dikpora kepad sekolah sekolah yang berada di bawah naungannya, baik itu sekolah negeri ataupun sekolah swasta. Persoalan ini muncul karena sekolahsekolah masih menggunakan sistem 6 hari kerja. Inilah yang menjadi latar belakang masalah, sehingga penulis bermaksud untuk melakukan penelitian dengan judul : "Evaluasi Kebijakan 5 Hari Kerja terhadap pencapaian Standar Pelayanan Minimal Pada Dinas Pendidikan Kota Mataram". (Studi Kasus di Dinas Pendidikan Kota Mataram).

\section{METODE PENELITIAN}

Penelitian ini menggunakan metode studi kasus dengan pendekatan kualitatif (Arikunto, 2013). Pendekatan penelitian kualitatif digunakan dalam penelitian ini karena penelitian ini bermaksud untuk memahami bagaimana proses rekrutmen pengawas sekolah dasar yang dilaksanakan oleh Dinas Pendidikan dan Kebudayaan Kabupaten Lombok Timur, dan untuk memahami pola rekrumen tersebut, peneltian ini menggunakan metode studi kasus.

Jenis data penelitian ini terdiri dari data primer dan data sekunder. Menurut Riyanto (2007) data primer adalah keterangan yang diperoleh peneliti melalui penyelidikan langsung dari gejalanya atau dari sumbernya, sedangkan data sekunder adalah keterangan yang diperoleh seorang peneliti, tetapi melalui sumber lain, baik lisan maupun tulisan.

Teknik pengumpulan data menggunakan lembar observasi, wawancara, dokumentasi. Teknik analisis data menggunakan tiga alur kegiatan yaitu pengumpulan data, reduksi data, penyajian data dan penarikan kesimpulan.

Keabsahan data dalam penelitian kualitatif meliputi empat teknik yaitu : kredibilitas (credibility), keteralihan (transferabilitas), depenabilitas (dependability), konfirmabilitas (confirmability). 


\section{HASIL DAN PEMBAHASAN}

\section{Kebijakan 5 hari kerja untuk meningkatkan kinerja pegawai pada Dinas Pendidikan Kota Mataram}

Pembangunan pendidikan di Kota Mataram merupakan proses panjang untuk meningkatkan daya saing masyarakat Kota Mataram maupun bangsa Indonesia pada umumnya. Berbagai terobosan program dan kegiatan yang telah dilaksanakan sampai dengan tahun 2010 telah memberikan hasil yang menggembirakan. Hal ini ditunjukkan dengan adanya pencapaian Indeks Pembangunan Manusia (IPM) Kota Mataram yang semakin meningkat setiap tahunnya.

IPM merupakan suatu indeks komposit yang mencakup tiga bidang pembangunan masyarakat yang dianggap sangat mendasar yaitu bidang kesehatan yang diukur dengan angka harapan hidup, bidang pendidikan yang diukur dengan angka melek huruf dan rata-rata lama sekolah serta ekonomi yang diukur dengan rata-rata pengeluaran perkapita. Berdasarkan hasil perhitungan IPM oleh BPS, terlihat bahwa status pembangunan masyarakat di Kota Mataram pada tahun 2009 sudah mencapai tingkat menengah sebesar 71,41 atau naik sebesar 3,2 point dengan menduduki peringkat ke-1 dari kabupaten/kota lain di NTB.

Sebagai salah satu bagian dari organisasi Pemerintah Daerah di Kota Mataram, Dinas Pendidikan Kota Mataram mempunyai tugas melaksanakan tugas pokok dan fungsi Departemen Pendidikan Nasional dalam wilayah Kota Mataram dan menyelenggarakan fungsi-fungsi seperti meningkatkan akses masyarakat terhadap pendidikan, meningkatkan kesejahteraan tenaga pendidik meningkatkan mutu pendidikan dilingkungan Kota Mataram. Mengingat fungsi dan kegiatan pokok Dinas Pendidikan Kota Mataram tersebut sejalan dengan Visi dan Misi yang diembannya, maka kesemuanya diimplementasikan atau dituangkan dalam dokumen yang bernama program kerja atau rencana kerja yang akan dilakukan oleh masing-masing bagian yang ada pada Dinas Pendidikan Kota Mataram tersebut. Baik tidaknya kinerja atau pencapaian hasil tersebut tercermin dari seberapa jauh target program kerja tersebut direalisasikan, dan hal ini tentunya dapat dilihat dari Laporan Akuntabilitas Kinerja (LAKIP) Dinas Pendidikan Kota Mataram.

Kinerja pegawai Dinas Pendidikan Kota Mataram terhadap 5 hari kerja memberikan respon yang positif. Penggunaan waktu dan disiplin kerja dalam kebijakan lima hari kerja memberikan sumbangan positif terhadap produktivitas kerja pegawai Dinas Pendidikan di Kota Mataram; (2) Intensitas kerja dalam kebijakan lima hari kerja memberikan sumbangan positif terhadap produktivitas kerja pegawai cabang dinas pendidikan nasional Kota Mataram; (3) Inisiatif kerja dalam kebijakan lima hari kerja memberikan sumbangan positif terhadap produktivitas kerja pegawai dinas pendidikan di Kota Mataram; (4) Suasana kerja dalam kebijakan lima hari kerja memberikan sumbangan positif terhadap produktivitas kerja pegawai cabang dinas pendidikan Kota Mataram; (5) Kebijakan lima hari kerja, baik yang menyangkut penggunaan waktu dan disiplin kerja, intensitas kerja, inisiatif kerja, serta suasana kerja dalam kebijakan lima hari kerja secara bersama-sama memberikan sumbangan positif terhadap produktivitas kerja pegawai dinas pendidikan nasional Kota Mataram. Pegawai merasa senang dengan kebijakan yang diterapkan oleh Dinas Pendidikan sehingga kinerja pegawai dapat meningkat.

Berdasrkan hasil wawancara mendalam sebagian besar informan menyatakan bahwa penerapan lima hari kerja membentuk waktu pelayanan menjadi lebih panjang

"...Persepsi saya terhadap 5 hari
kerja di Dinas Pendidikan Kota
Mataram secara umum baik karena
waktu pelayanannya lebih
panjang dikarenakan waktu kerja
dimulai jam 7.00-16.00 WITA"
(Informan 1)

Pendapat informan ini juga dipertegas oleh informan lain

"ya yang 5 hari lebih panjang jelasnya, yang 6 hari itu lebih pendek 
Cuma harinya lebih banyak gitu aja"(Iinforman 2 dan 3 ).

Unsur kelebihan lain yang didapat dari hasil wawancara mendalam dapat dilihat dari petikan beberapa di bawah ini yang menandakan pelayanan menjadi lebih cepat:

"bagi saya sendiri bahwa 5 hari kerja itu

kami anggap yang lebih efektif $\quad k a$ rnasemua bidang menyelesaikan tugas sesuai pokoknya masingmasing untuk meningkatkan standar pelayanan minimal di dinas pendidikan Kota Mataram”. (Inforrman 10)

"waktu itu juga. kalau yang 6 hari kerjaya untuk mengurus bebarapa dokumen besoknya baru bisa selesai. Sedangkan kalau yang hari kerja dokumen yang akan kita urus akan xepat diurus dan diproses" (Informan 4).

Dari hasil wawancara di atas, waktu pelanyanan menjadi lebih efektif, lebih cepat dapat menghemat biaya dan waktu kerja. Unsur kelebihanlain dari penerapan lima hari kerja dapat diungkapkan beberapa pernyataan wawancara peneliti dengan informan yang menyatakan tingkat keadilan pelayanan yaitu:

"adil pak.Terusya untuk sementara setaunya saya selama ini lumayan. Baguslah" (Informan 5)

"kalau saya liat dari sekarang untuk pelayanan masyarakat sudah cukup adil karna sampai disini kita sudah disodorkan nomor antrean dan kita disuruh mendaftar dengan nomor itu" (Informan 6)

Kelebihan lain yang didapat dari hasil wawancara peneliti bahwa adanya efisiensi waktu dan biaya yang dipertegas dari kutipan di bawah ini:

"yang cuma yang itu seperti saya katakan tadi yang 5 hari kerja itu lebih efisien karena kalau besoknya disuruh kesini kan harusnya 2 kali nyewa" (Informan 7)
Penerapan lima hari kerja yang telah dilaksanakan dari hasil observasi dan wawancara mendalam ditemukan kualitas $p$ elayanan dinas pendidikan Kota Mataran dikatagorikan lebih baik dari beberapa hasil wawancara yaitu

"Kalau menurut saya ya yang udah berjalan selama ini udah bagus tapi perlu ditingkatkan lagi" (Informan 8) Pernyataan ini juga dipertegas oleh informan lain yang menyatakan

"Kalau menurut saya pelayanan udah cukup maksimal.... itu yang menurut saya setiap saya ke kantor mengurus beberapa dokumen terkait pendidikan anak saya itu selalu cepat tidak terlalu lama saya menunggu dan pelayanan cukup baik lah" (informan 9)

Nilai kelebihan dari informasi yang dikumpulkan peneliti yaitu: waktu pelaya nan menjadi lebih panjang, efisiensi waktu dan biaya, akses

tempat pelayanan terjangkau, pelayanan me njadi lebih cepat,tingkat keadilan pelayanan berjalan baik,

Secara empiris pelaksanaan enam hari ke rja yang awalnya dilakukan dan dimulai dari pukul (07.00 - 14.00 WITA (Hari Senin Kamis) dimulai pukul (07.00 - 13.00 hari Jumat dan Sabtu). Penggunaan waktu kerja rerata 6,7 jam tiap hari dan kemudian pada saat penerapan lima hari kerja yang dimulai dari hari Senin sampai dengan hari Jumat disetiap harinya dimulai dari pukul (07.00 WITA dan berakhir pada pukul 16.00 WITA dengan rerata 5 jam tiap hari yang menandakan jam pelayanan menjadi lebih panjang

Penanganan yang cepat berpengaruh terhadap efisiensi kerja baik dari masyrakat yang membutuhkan satu kali transportasi dan penggunaan waktu menjadi leih hemat. Parameter utamayang digunakandalam menil ai perilaku adalah biaya (uang, waktu, dan e nergi) yang dikeluarkan dengan membandingkan pada hasil yang dicapai atau yang dikenal dengan kriteria efisiensi

Faktor lain yang berperan dalam peningkatan kinerja pegawai adalah 
dukungan lingkungan kerja yang baik dan kondusif. Apabila dalam lingkungan kerja seorang pegawai mendapatkan apa yang diharapkan seperti peluang promosi yang adil, pendapatan yang memadai, rekan kerja dan atasan yang menyenangkan maka pegawai akan merasa lebih nyaman dalam bekerja sehingga produktivitas pegawai dapat lebih meningkat. Wahyudi \& Suryono (2006) menyatakan bahwa lingkungan kerja harus mempertimbangkan tuntutan kerja, persyaratan interaksi formal dan kebutuhan sosial ketika mengambil keputusan mengenai konfigurasi ruangan, desain interior, penetapan peralatan dan yang serupa.

Hubungan dan pengaruh lingkungan kerja terhadap peningkatan kinerja terlihat dalam hasil penelitian Wahyudi \& Suryono (2006) menunjukkan adanya hubungan positif kepemimpinan, motivasi dan lingkungan kerja terhadap kinerja. Dikemukakan pula oleh Sampurno, \& Wibowo (2015) bahwa lingkungan kerja berpengaruh positif dan signifikan terhadap kinerja. Hasil penelitian tersebut menunjukkan bahwa faktor lingkungan kerja berperan terhadap pening-katan kinerja pegawai.Kepuasan kerja merupakan salah satu faktor lain yang dapat memengaruhi kinerja pegawai.

Pegawai yang memperoleh kepuasan kerja akan bersemangat dalam melaksanakan tugas yang dibebankan dengan penuh rasa tanggung jawab sehingga kepuasan kerja pegawai perlu mendapatkan perhatian manajemen. Kepuasan pegawai dapat didorong dengan memberikan kepercayaan dengan cara melibatkan pegawai dalam pengambilan keputusan, hal ini dapat menaikkan kepuasan dan meningkatkan komitmen pegawai yang selanjutnya akan menumbuhkan rasa memiliki di antara pegawai.

$$
\text { Robert \& Angelo (2005) }
$$

mendefinisikan kepuasan kerja adalah efektivitas atau respon emosional terdahap berbagai aspek pekerjaan. Rudolf (2014) menyatakan bahwa kepuasan kerja adalah suatu sikap umum terhadap pekerjaan seseorang sebagai perbedaan antara banyaknya ganjaran yang diterima dan banyaknya yang diyakini yang seharusnya diterima.

Kepuasan kerja juga dapat timbul karena adanya suasana nyaman yang dirasakan pegawai dalam melaksanakan pekerjaannya, baik kenyamanan yang timbul dari lingkungan internal maupun lingkungan eksternal, pada dasarnya dapat mendorong gairah bekerja dan kinerja pegawai yang bersangkutan dalam menyelesaikan tugastugas pekerjaannya, sehingga pada akhirnya dapat mendorong peningkatan kinerja pegawai yang bersang-kutan. Pengaruh kepuasan kerja terhadap kinerja pegawai tergambar dalam hasil penelitian Hermawati (2018) menunjukkan bahwa kepuasan kerja, peran kepemimpinan dan komitmen organisasi berpengaruh positif dan signifikan terhadap kinerja pegawai. Temuan lain dari hasil penelitian Handoyo (2009) menunjukkan kepuasan kerja berpengaruh signifikan terhadap kinerja pegawai.

Pada sisi lain, faktor penentu kinerja yang juga bersumber dari dalam diri pegawai adalah adanya keinginan yang kuat dari dalam diri pegawai itu sendiri untuk mau bekerja secara optimal yang dalam hal ini diimplementasikan dalam bentuk motivasi kerja pegawai (Pérez-Asenjo, 2011). Motivasi lebih banyak membicarakan tentang bagaimana caranya mendorong gairah kerja bawahan agar mereka mau bekerja keras dalam memberikan semua kemampuan dan ketrampilannya untuk mewujudkan tujuan organisasi (Henly \& Lambert, 2014). Karena motivasi kerja tersebut muncul dari dalam diri pegawai /karyawan, tentunya untuk memotivasi pegawai / karyawan tersebut haruslah disadari bahwa orang akan mau bekerja keras dengan harapan akan dapat memenuhi kebutuhan dan keinginan keinginannya dari hasil pekerjaan yang telah dilakukannnya (Choi, 2011). Hal lain juga yang mempengaruhi peningkatan kinerja pegawai ialah motivasi kerja (Hatler, et al., 2010).

Dari aspek motivasi kerja, Hasibuan (2001) menyebutkan bahwa ada beberapa inidikasi yang memperlihatkan seorang 
karyawan termotivasi atau tidak termotivasi dalam bekerja salah satu diantaranya adalah datang terlambat dan pulang cepat serta tidak masuk kerja tanpa alasan yang jelas.

Hasil penelitian yang dilakukan Mulyadi dan Marliana (2010) menyatakan bahwa motivasi mempunyai pengaruh positif dan signifikan terhadap kinerja karyawan, disiplin kerja tidak mempunyai pengaruh positif dan signifikan terhadap kinerja karyawan. Selain itu Netmeyer, et al., (2005) menyatakan bahwa motivasi kerja berpengaruh dan signifikan terhadap kinerja karyawan, kemampuan kerja berpengaruh dan signifikan terhadap kinerja karyawan. Kinerja karyawan berpengaruh dan signifikan terhadap kepuasan kerja (Rudolf, 2014).

Pada pelaksanaan enam hari kerja didapati banyak kejadian pemanfaatan waktu kerja yang tidak sejalan dengan produktivitas kerja, misalnya banyak tugas-tugas diabaikan, dan bahkan banyak pegawai sengaja melanggar (tidak disiplin) (Netmeyer, et al., 2005). Sikap mental seperti ini tentu saja tidak akan menimbulkan suasana kerja yang optimis, apalagi diharapkan untuk menciptakan metode dan sistem kerja yang produktif di semua perangkat kerja yang ada. Rahmawati, et al., (2020) menyatakan bahwa banyak di antara para pekerja atau pegawai/karyawan yang mengisi waktu kerjanya dengan duduk-duduk mengobrol, baca koran, menelpon keluarga atau teman aataupun izin ke luar kantor untuk urusan-urusan yang tidak mempunyai kaitan sama sekali dengan tugas pekerjaanya.

Falsafah kerja santai juga kurang pada tempatnya. Istilah tersebut tidak cocok dalam suasana pembangunan. Santai atau rileks adalah selingan di antara dua masa kerja produktif, bukan berada pada masa kerja produktif. Meskipun demikian, suasana santai diperlukan untuk memulihkan kondisi tubuh dan otak setelah bekerja penuh selama satu masa tertentu, misalnya satu minggu atau lima hari. Dalam kerangka inilah muncul pemikiran tentang lima hari kerja, khususnya di lingkungan pemerintahan. Dengan harapan para pegawai dapat memulihkan kondisi tubuh dan otak, dengan beristirahat atau bersantai pada akhir pekan (sabtu dan minggu), sehingga pada hari scnin tubuh dan otak mereka sudah segar dan siap kerja produktif, dan yang paling penting tidak santai atau malas-malasan pada waktu kerja produktif.

Penelitian ini bertentangan dengan penelitian yang dilakukan oleh (Neumark dan Postlewaite, 1998; Akerlof dan Kranton, 2000; Goldsmith et al., 2004; Pérez-Asenjo, 2011) mereka mengungkapkan bahwa keputusan penawaran tenaga kerja dunia nyata juga tampaknya lebih dibatasi sisi permintaan daripada yang diakui model tradisional. Artinya, pekerja seringkali tidak bebas memilih jam kerja Karena "batasan jam kerja" yang diberlakukan oleh pemberi kerja seperti jam kerja minimum atau panjang shift tetap, karyawan seringkali dipaksa untuk bekerja lebih lama dari yang mereka inginkan pada awalnya (Golden dan Wiens-Tuers, 2006)

\section{Kebijakan 5 hari kerja meningkatkan standar pelayanan minimal pada Dinas Pendidikan Kota Mataram}

Subyek penelitian ini adalah kepala Dinas. Wawancara dengan kepala Dinas mendapatkan hasil bahwa 5 kerja ini bagi Dinas sangat membantu dan memudahkan birokrasi yang ada di lingkup pemerintahan kota Mataram sebagaimana dia katakan dalam wawancara dengan peniliti sebagai berikut :

"Dalam menjalakan tugas sebagi ASN di Pemkot Mataram sebagai kepala Dinas saya berpendapat bahwa dengan 5 hari kerja ini membantu dan memudahkan alur birokrasi .(W.KD. 01, 13-8-2018)"

Konsep Implementasi Kebijakan Standar Pelayanan Minimal (SPM) Dinas Pendidikan Kota Mataram. Implementasi kebijakan adalah aturan tertulis yang merupakan keputusan formal organisasi, yang bersifat mengikat, yang mengatur perilaku dengan tujuan untuk menciptakan tata nilai baru dalam masyarakat. Kebijakan akan menjadi rujukan utama para anggota organisasi atau anggota masyarakat dalam 
berprilaku dan Kebijakan pada umumnya bersifat problem solving dan proaktif. Berbeda dengan Hukum (Law) dan Peraturan (Regulation), kebijakan lebih adaptif dan interpratatif, meskipun kebijakan juga mengatur "apa yang boleh, dan apa yang tidak boleh". Kebijakan juga diharapkan dapat bersifat umum tetapi tanpa menghilangkan ciri lokal yang spesifik. Kebijakan harus memberi peluang diinterpretasikan sesuai kondisi spesifik yang ada (Kurnialloh, 2013).

Salah satu kebijakan pendidikan adalah implementasi Standar Pelayanan Minimal Dinas Pendidikan Kota Mataram (SPM) yang dijadikan salah satu tolok ukur kinerja pelayanan Dinas Pendidikan Kota Mataram. Sebagaimana diatur dalam Peraturan Menteri Pendidikan dan Kebudayaan Nomor 23 Tahun 2013 Tentang Perubahan Atas Permendiknas Nomor 15 Tahun 2010 bahwa penyelenggaraan Dinas Pendidikan Kota Mataram sesuai SPM merupakan kewenangan kabupaten/kota. Pemerintah kabupaten/kota wajib melakukan pengembangan kapasitas untuk mencapai SPM, sedangkan pemerintah dalam hal ini Kementerian Pendidikan dan Kebudayaan memfasilitasi pengembangan kapasitas melalui peningkatan kemampuan sistem, kelembagaan, personil dan keuangan, baik ditingkap pusat, Provinsi, Kabupaten/Kota, dan satuan pendidikan.

Secara umum pembangunan sektor pendidikan di Indonesia mengalami kemajuan yang sangat nyata, khususnya perbaikan akses Dinas Pendidikan Kota Mataram dan peningkatan kualitas pelayanannya. Meskipun demikian masih terjadi disparitas yang cukup nyata terhadap pelayanan pendidikan di beberapa kabupaten/kota di Indonesia. Kementerian Pendidikan dan Kebudayaan telah banyak membantu kabupaten/kota untuk mencapai SPM Dinas Pendidikan Kota Mataram, namun masih banyak kabupaten/kota tertentu yang memerlukan bantuan teknis lebih intensif (Dirjen Dikdas, 2015).

Terkait dengan hal tersebut, sesuai amanat Undang-Undang Nomor 32 Tahun 2004 tentang Pemerintah Daerah telah secara jelas mendelegasikan kewenangan penyelenggaraan urusan wajib pemerintahan kepada pemerintah provinsi dan kabupaten/kota. Sesuai dengan Peraturan Pemerintah Nomor 38 Tahun 2007, urusan pendidikan merupakan salah satu pelayanan wajib yang harus diselenggarakan oleh pemerintah kabupaten/kota. Lebih lanjut Undang-Undang Nomor 32 Tahun 2004 menyatakan bahwa penyelenggaraan pelayanan wajib yang didesentralisasikan perlu diatur dalam Standar Pelayanan Minimal (SPM).

Sesuai dengan Peraturan Pemerintah Nomor 65 Tahun 2005, SPM adalah ketentuan mengenai jenis dan mutu pelayanan dasar yang merupakan urusan wajib daerah yang berhak diperoleh setiap warga negara secara minimal, terutama yang berkaitan dengan pelayanan dasar. Penerapan SPM dimaksudkan untuk menjamin akses dan mutu bagi masyarakat untuk mendapatkan pelayanan dasar dari pemerintah kabupaten/kota sesuai dengan ukuran yang ditetapkan oleh Pemerintah.

(Dirjen Dikdas, 2015). Oleh karena itu, dalam pelayanan Dinas Pendidikan Kota Mataram harus memperhatikan indikatorindikator yang ada dalam Standar Pelayanan Minimal Dinas Pendidikan Kota Mataram.

Fungsi implementasi kebijakan pendidikan, sebagai berikut: pertama: pedoman untuk bertindak; kedua, pembatas perilaku; dan ketiga: bantuan bagi pengambil keputusan. Berdasarkan penegasan di atas dapat disimpulkan bahwa fungsi kebijakan dibuat untuk menjadi pedoman dalam bertindak, mengarahkan kegiatan dalam organisasi untuk mencapai tujuan yang telah ditetapkan.

Dengan kata lain, kebijakan merupakan garis umum untuk bertindak bagi pengambilan keputusan pada semua jenjang organisasi (Kurnialloh, 2013). Terkait dengan penjelasan di atas, kebijakan tentang Standar Pelayanan Minimal (SPM) Dinas Pendidikan Kota Mataram tentu membawa konsekuensi logis bagi pemerintah daerah dan satuan pendidikan dalam upaya pemenuhan 27 
Indikator Pencapaian SPM Dinas Pendidikan Kota Mataram secara bertahap.

Dalam tahapan pelaksanaannya, pemerintah daerah dan satuan pendidikan perlu duduk bersama merumuskan strategi pemenuhan SPM Dikdas dan target waktu yang akan ditempuh untuk memenuhi 27 Indikator Pencapaian (IP). Hal ini akan mudah diwujudkan apabila pemerintah daerah dan stakeholders terkait pendidikan memiliki roadmap/peta jalan tentang pemenuhan Standar Pelayanan Minimal (SPM) Dinas Pendidikan Kota Mataram.

Analisis Kebijakan Standar Pelayanan Minimal (SPM) Dinas Pendidikan Kota Mataram Kebijakan implementasi SPM Dinas Pendidikan Kota Mataram sudah dimulai sejak peraturan pemerintah diterbitkan tahun 2010. Namun demikian, pelaksanaannya belum optimal sampai muncul Permendikbud No. 23 Tahun 2013 sebagai perubahan peraturan sebelumnya.

Dalam Permendikbud No 23 Tahun 2013 pasal 6 ayat 3 disebutkan target pencapaian pelayanan dasar bidang pendidikan harus tercapai pada akhir tahun 2014. Realitanya, belum semua satuan pendidikan baik SD/MI maupun SMP /MTs memahami dan melaksanakan Standar Pelayanan Minimal (SPM) Dinas Pendidikan Kota Mataram.

Beruntung di tahun 2015, pemerintah pusat menginisiasi Program Pengembangan Kapasitas Standar Pelayanan Minimal Dinas Pendidikan Kota Mataram (PKP-SPM Dikdas) yang bersinergi dengan ADB dan Europen Union memberikan dana hibah kepada Kabupaten/Kota di seluruh Indonesia. Alhasil, program tersebut bergulir selama dua tahun yang dimulai tahun 2015 dan 2016 kepada kabupaten/kota yang terpilih dan memenuhi persyaratan. Bahkan masih ada perpanjangan waktu untuk menuntaskan program dan kegiatan PKP-SPM Dikdas sampai akhir tahun 2017 berdasarkan peringkat masingmasing Kabupaten/Kota di Indonesia.

Program tersebut sasarannya bukan fisik atau sarana prasarana, tetapi pengembangan kapasitas yang berujud pelatihan, workshop, FGD, pengayaan, analisis data, dan penguatan materi pelatihan. Sedangkan subjek sasaran adalah pengawas sekolah, kepala sekolah, pejabat struktural, pembina yayasan pendidikan, dewan pendidikan, dewan sekolah, petugas laboratorium dan perpustakaan.

Kebijakan lima hari kerja ada hubungan positif dan signifikan dengan produktifitas kerja bagi Pegawai Negri Sipil di Dinas Pendidikan Kota Mataram. Faktor persepsi kebijakan lima hari kerja menyumbang $17,4 \%$ terhadap produktifitas kerja. Semakin tinggi persepsi kebijakan lima hari kerja pegawai semakin meningkat (Wijanarti, 2016). Setiap pelanggan memiliki keinginan dan harapan yang memunuhi beberapa hal yaitu: effecient, affordoble, accessible, equity, timeless, dan continuity.

Berdasarkan hasil wawancara yang telah dilakukan didapatkan hasil bahwa penerapan sistem lima hari kerja menurut perpektif pelanggan eksternal memiliki kekurangan yaitu: fleksibelitas hari pelayanan berkurang, kelehan dan penurunan fokus kinerja pegawai, sinergitas waktu pelayanan dan fasyankes lain belum sejalan.

Peluang yang dimiliki oleh masyarakat yang selama ini bisa menggunakan pada hari sabtu harus mulai merasa kehilangan dan menyesuaikan dengan perubahan sistem lima hari kerja. Kelemahan ini juga dapat ditemukan secara empiris dari hasil pengamatan langsung berdasrkan ketentuan UU Nomor 13 Tahun 2003 yang mengatur tentang ketenagakerjaan pada pasal 77 mengenai waktu kerja.

Menurut peneliti penerapan lima hari kerja memiliki kekurangan terhadap kelelahan dari tenaga pegawai, akibat dari penerapan sistem jam kerja yang panjang dengan jumlah kunjungan masyarakat yang cukup tinggi. Pernyataan ini dipertegas oleh hasil penelitian Platsidou, \& Agaliotis, (2008) yang menunjukkan bahwa burnout syndrome memiliki hubungan yang signifikan dengan beban kerja karyawan ( $p$ value $=0,005$ ). Beban kerja yang tinggi secata spesifik berpengaruh pada dimensi burnout synndrome yaitu physical and emotional 
Jurnal Ilmu Sosial dan Pendidikan

Vol. 4. No. 4 November 2020

http://ejournal.mandalanursa.org/index.php/JISIP/index

Terakreditasi Peringkat 5 (No. SK: 85/M/KPT/2020)

exhaustion (Ghanizadeh \& Jahedizadeh, 2015).

\section{KESIMPULAN}

Pelaksanaan lima hari kerja pada Dinas

Pendidikan Kota Mataram untuk meningkatkan Standar Pelayanan Minimal termasuk kategori baik, pelaksanaan pelayanan termasuk kategori sangat baik.

Pelaksanaan lima hari kerja pada Dinas Pendidikan Kota Mataram dalam meningkatkan Standar Pelayanan Minimal berpengaruh positif terhadap para pegawai dan semua elemen terkait

\section{REFERENSI}

Akerlof, G. A., \& Kranton, R. E. (2000). Economics and identity. The quarterly journal of economics, 115(3), 715-753.

Arikunto, S. (2013). Prosedur Penelitian Suatu Pendekatan Praktik. Jakarta: PT Rineka Cipta.

Choi, S. (2011). Organizational justice and employee work attitudes: The federal case. The American Review of Public Administration, 41(2), 185-204.

Ghanizadeh, A., \& Jahedizadeh, S. (2015). Teacher burnout: A review of sources and ramifications. Journal of Education, Society and Behavioural Science, 24-39.

Golden, L., \& Wiens-Tuers, B. (2006). To your happiness? Extra hours of labor supply and worker well-being. The Journal of Socio-Economics, 35(2), 382-397.

Goldsmith, A. H., Sedo, S., Darity Jr, W., \& Hamilton, D. (2004). The labor supply consequences of perceptions of employer discrimination during search and on-the-job: Integrating neoclassical theory and cognitive dissonance. Journal of Economic Psychology, 25(1), 15-39.

Handoyo, M. (2009). Pengaruh Motivasi Kepuasan Kerja, dan Komitmen Organisasi terhadap Kinerja Pegawai Pada Disnakertrans

\section{Provinsi Daerah Istimewa Yoyakarta.}

Harter, J. K., Schmidt, F. L., Asplund, J. W., Killham, E. A., \& Agrawal, S. (2010). Causal impact of employee work perceptions on the bottom line of organizations. Perspectives on Psychological Science, 5(4), 378389.

Hasibuan, M. S. (2001). Manajemen Sumber Daya Manusia, Bumi Aksara.

Henly, J. R., \& Lambert, S. J. (2014). Unpredictable work timing in retail jobs: Implications for employee work-life conflict. Ilr Review, 67(3), 986-1016.

Mangkunegara, A. P., \& Prabu, A. (2009). Manajemen sumber daya manusia. Bandung: PT. Remaja Rosdakarya.

Mulyadi, H., \& Marliana, N. (2010). Pengaruh Motivasi Dan Disiplin Kerja Karyawan Terhadap Kinerja Karyawan Pada Departemen Weaving Pt. Adetex Cabang Banjaran Kab. Bandung. Strategic: Jurnal Pendidikan Manajemen Bisnis, 10(1), 40-51.

Netemeyer, R. G., Maxham III, J. G., \& Pullig, C. (2005). Conflicts in the work-family interface: Links to job stress, customer service employee performance, and customer purchase intent. Journal of marketing, 69(2), 130-143.

Neumark, D., \& Postlewaite, A. (1998). Relative income concerns and the rise in married women's employment. Journal of public Economics, 70(1), 157-183.

Pasolong, H. (2007). Teori administrasi publik. Bandung: Alfabeta.

Pérez-Asenjo, E. (2011). If happiness is relative, against whom do we compare ourselves? Implications for labour supply. Journal of Population Economics, 24(4), 1411-1442.

Platsidou, M., \& Agaliotis, I. (2008). Burnout, job satisfaction and instructional assignment-related sources of stress in Greek special 
education teachers. International journal of disability, development and education, 55(1), 61-76.

Rahmawati, E., Malik, D., \& Fathoni, A. (2020). The Effect Of Burnout And Work Discipline With Leadershias A Mediating Variable On Employee Performance (Case Study at PT. Sri Indah Labetama, Boyolali Regency). Journal of Management, 6(6)

Ratminto \& Winarsih.S. A. (2012). Manajemen Pelayanan. Pustaka Pelajar.

Riyanto, Y. (2007). Metodologi Penelitian Pendidikan kualitatif dan kuantitatif.

Rudolf, R. (2014). Work shorter, be happier? Longitudinal evidence from the Korean five-day working policy. Journal of happiness studies, 15(5), 1139-1163.

Sampurno, D., \& Wibowo, A. (2015). Kepemimpinan Kepala Sekolah, Lingkungan Kerja, Motivasi Kerja, Dan Kinerja Guru Di SMK Negeri 4 Pandeglang. Jurnal Pendidikan Ekonomi Dan Bisnis (JPEB), 3(2), 165-180.

Wahyudi, A., \& Suryono, J. (2006). Analisis Pengaruh Gaya Kepemimpinan, Motivasi, dan Lingkungan Kerja terhadap Kinerja Pegawai. Jurnal Manajemen Sumber Daya Manusia, 1(1), 1-14.

Wijanarti, N. (2016). Evaluasi Pencapaian Standar Pelayanan Minimal Berdasarkan Prinsip Good Governance Di Sekolah Dasar Negeri. Kelola: Jurnal Manajemen Pendidikan, 3(2), 207-218. 